\title{
PENGARUH SKEMA KOMPENSASI REWARD, PUNISHMENT TERHADAP FRAUDELENT FINANCIAL REPORTING DENGAN MOTIVASI KERJA SEBAGAI VARIABEL MODERATING
}

\author{
Yogo Noto \\ Prodi Akuntansi Universitas Negeri Yogyakarta \\ yogonoto11@gmail.com \\ Amanita Novi Yushita \\ Staf Pengajar Jurusan Pendidikan Akuntansi Universitas Negeri Yogyakarta
}

\begin{abstract}
Abstrak : Pengaruh Skema Kompensasi Reward, Punishment Terhadap Fraudelent Financial Reporting Dengan Motivasi Kerja Sebagai Variabel Moderating. Penelitian ini bertujuan untuk mengetahui: (1) pengaruh Skema Kompensasi Reward terhadap Fraudelent Financial Reporting, (2) pengaruh Skema Kompensasi Punishment terhadap Fraudelent Financial Reporting, (3) pengaruh Skema Kompensasi Reward dan Punishment terhadap Fraudelent Financial Reporting, (4) Motivasi Kerja memoderasi pengaruh Skema Kompensasi Reward terhadap Fraudelent Financial Reporting (5) Motivasi Kerja memoderasi pengaruh Skema Kompensasi Punishment terhadap Fraudelent Financial Reporting, (6) Motivasi Kerja memoderasi Skema Kompensasi Reward dan Punishment terhadap Fraudelent Financial Reporting. Penelitian ini merupakan penelitian eksperimen. Penelitian ini menggunakan populasi pegawai bagian keuangan Universitas Negeri Yogyakarta yang berjumlah 82 responden dan yang dapat diolah sebanyak 75 data responden. Data dalam penelitian ini dianalisis dengan Uji ANOVA untuk mengetahui pengaruh utama dari tiap variabel. Hasil dari penelitian menunjukan bahwa seluruh hipotesis dapat diterima dan treatment Skema Kompensasi terhadap Fraud berpengaruh selain itu variabel Motivasi Kerja juga memperkuat pengaruh terhadap variabel keduanya antara Skema Kompensasi terhadap Fraudelent Financial Reporting.
\end{abstract}

Kata kunci: Skema Kompensasi, Reward, Punishment, Motivasi Kerja, Fraudelent Financial Reporting

\begin{abstract}
The Effect of Reward, Punishment Compensation Scheme to Fraudelent Financial Reporting with Work Motivation as the Moderating Variable. This study aims to determine: (1) the effect of Reward Compensation Scheme to Fraudelent Financial Reporting, (2) the effect of Punishment Compensation Scheme to Fraudelent Financial Reporting, (3) the effect of Reward and Punishment Compensation Scheme to Fraudelent Financial Reporting, (4) Work Motivation moderating the effect of Reward Compensation Scheme to Fraudelent Financial Reporting, (5) Work Motivation moderating the effect of Punishment Compensation Scheme to Fraudelent Financial Reporting, (6) Work Motivation moderating the effect of Reward and Punishment Compensation Scheme to Fraudelent Financial Reporting. This study used the population of financial section employee of State University of Yogyakarta totaling 82 respondents and analyzed data can only used 75 respondents. The data were analyzed using ANOVA to find out the main effect of each variable. The results showed that all hypothesis can be accepted and the Compensation Scheme take effect to the Fraud and variable Work Motivation also strengthen the influence of the variabels between Compensation Scheme and Fraudelent Financial Reporting.
\end{abstract}

Keywords: Compensation Scheme, Reward, Punishment, Work Motivation, Fraudelent Financial Reporting 


\section{JURNAL NOMINAL / VOLUME V NOMOR 1 / TAHUN 2016}

\section{PENDAHULUAN}

Sebuah organisasi merupakan satu kesatuan yang tak terpisahkan, yang terdiri dari individu yang memiliki latar belakang berbeda-beda dan saling bekerja sama satu dengan yang lain. Dalam sebuah organisasi setiap individu di dalamnya berusaha untuk mewujudkan tujuan bersama dengan memanfaatkan seluruh sumber daya yang ada. Demikian pula dengan instansi pemerintah yang merupakan sebuah contoh organisasi dimana seluruh anggota didalam organisasi tersebut harus berkerja bersamasama untuk mencapai tujuan organisasi. Pada perusahaan atau instansi, karyawan merupakan sumber daya yang penting dalam menentukan tercapainya tujuan. Namun, dalam pencapaian tujuan bukanlah hal yang mudah dilakukan karena diperlukan strategi untuk mencapainya. Masalah mendasar yang sering dihadapi perusahaan atau instansi adalah bagaimana mengelola sumber daya manusia untuk melakukan tugas dengan sebaik-baiknya dalam rangka mencapai tujuan yang telah ditetapkan. Selain melaksanakan tugas dengan baik karyawan juga diarahkan untuk menghindari kecurangan maupun tindakan tidak jujur dalam berkerja. Kecurangan maupun tindakan tidak jujur saat ini telah menarik banyak perhatian dan isu yang menonjol di berbagai negara. Kecurangan merupakan bentuk penipuan yang sengaja dilakukan sehingga dapat menimbulkan kerugian tanpa disadari oleh pihak yang dirugikan dan memberikan keuntungan bagi pelaku kecurangan. Moehirno, (2006) menjelaskan bahwa terdapat hubungan yang erat antara penghargaan dan prestasi karyawan. Dalam upaya meningkatkan keterbukaan karyawan usaha yang dilakukan perusahaan tidak akan terlepas dari berbagai hal, diantara kompensasi yang diberikan kepada karyawan dan juga motivasi yang ada dalam diri karyawan.

Menurut ACFE atau Association of Certified Fraud Examinations (2012) terdapat 1.388 kasus fraud diseluruh dunia. Kasus fraud ini juga semakin bertambah setiap tahun. Menurut data ACFE jumlah persentase penyalahgunaan aset yang terjadi pada tahun 2010 adalah 86,3\% sedangkan pada tahun 2012 jumlah presentase penyalahgunaan aset meningkat menjadi $86,7 \%$. Jenis fraud lain yang juga mengalami peningkatan adalah kasus korupsi dan kecurangan laporan keuangan. Pada tahun 2010 jumlah presentase kasus korupsi yang terjadi adalah 32,8\% dan pada tahun 2012 jumlah presentase kasus korupsi meningkat menjadi 33,4\%. Untuk kasus kecurangan laporan keuangan yang terjadi pada tahun 2010 adalah jumlah 4,8\% dan pada tahun 2012 meningkat menjadi 7,6\%. Dari data tersebut dapat dilihat bahwa jumlah kasus fraud yang mengalami peningkatan paling tinggi adalah kasus kecurangan laporan keuangan atau 


\section{JURNAL NOMINAL / VOLUME V NOMOR 1 / TAHUN 2016}

fraudulent financial reporting. Tindakan karyawan yang baik sangat diperlukan dalam upaya menjaga kredibilitas instansi tersebut. Karyawan biasanya menginginkan kompensasi sebanyak mungkin sedangkan perusahaan akan lebih memilih untuk mempertahankan gaji karyawan (Govindarajan, 2005:109). Karyawan dapat dipengaruhi oleh insentif yang positif maupun yang negatif, suatu insentif yang positif atau "reward" adalah suatu hasil yang meningkatkan kepuasan dari kebutuhan individual. Sebaliknya apabila insentif negatif atau "punishment" adalah suatu hasil yang mengurangi kepuasan dari kebutuhan tersebut. Insentif berupa reward adalah suatu rangsangan untuk memenuhi kebutuhan seseorang yang tidak mungkin diperolehnya apabila tidak bergabung dalam organisasi tersebut. Beberapa identifikasi masalah dalam penelitian ini adalah Fraudelent Financial Reporting akan meningkat pada sebuah instansi jika karyawan tidak mendapatkan sistem kompensasi reward (bonus, tunjangan, promosi) dan punishment (potongan gaji, surat peringatan, skorsing) yang tepat, selain itu belum adanya titik temu antara instansi atau perusahaan dengan karyawan mengenai besarnya kompensasi dan karyawan sebagai pihak yang dinilai kinerjanya cenderung akan meminta gaji dan kompensasi yang besar sedangkan perusahaan atau instansi akan lebih memilih mempertahankan gaji dan kompensasi tetap. Belum adanya dorongan motivasi kerja bagi setiap individu oleh instansi yang pada nantinya karyawan akan berkerja sesuai dengan harapan perusahaan.

Tujuan penelitian ini untuk mengetahui pengaruh Skema Kompensasi Reward terhadap Fraudelent Financial Reporting, mengetahui pengaruh Skema Kompensasi Punishment terhadap Fraudelent Financial Reporting, mengetahui pengaruh Skema Kompensasi Reward dan Punishment terhadap Fraudelent Financial Reporting, mengetahui Motivasi Kerja memoderasi pengaruh Skema Kompensasi Reward terhadap Fraudelent Financial Reporting, mengetahui Motivasi Kerja memoderasi pengaruh Skema Kompensasi Punishment terhadap Fraudelent Financial Reporting dan untuk mengetahui Motivasi Kerja memoderasi pengaruh Skema Kompensasi Reward dan Punishment terhadap Fraudelent Financial Reporting. Manfaat dari penelitian ini diharapkan memberikan sumbangan terhadap perkembangan ilmu pengetahuan khususnya dalam bidang akuntansi keperilakuan yang berkaitan dengan perilaku karyawan, selain itu diharapkan dapat menjadi referensi bagi penelitian selanjutnya khususnya dalam bidang akuntansi keperilakuan dan akuntansi manajemen. Hasil penelitian ini berguna untuk menambah pengetahuan dan sebagai wahana dalam menerapkan ilmu 


\section{JURNAL NOMINAL / VOLUME V NOMOR 1 / TAHUN 2016}

yang telah dipelajari khususnya dalam bidang ilmu akuntansi keperilakuan dan akuntansi manajemen. Hasil penelitian ini berguna bagi instansi organisasi atau perusahaan untuk menentukan skema kompenasai yang sesuai dengan tipe karyawan yang ada dalam instansi tersebut, sehingga karyawan dapat bekerja sesuai dengan yang diharapkan.

Dalam penelitian ini terdapat beberapa penelitian yang dapat digunakan sebagai referensi. Penelitian tersebut adalah Peneliti mengacu pada penelitian yang dilakukan oleh R. Lynn Hanan, Vicky B. Hoffman, dan Donald V.Moser (2004) yang berjudul "Bonus versus Penalty: Does Contract Frame Affect Employee Effort?". Persamaan penelitian ini dengan penelitian yang dilakukan adalah penggunaan variabel independen yakni skema kompensasi bonus dan denda. Perbedaan penelitian ini terletak pada penambahan variabel moderating yakni motivasi kerja. Penelitian juga mengacu pada penelitian yang dilakukan oleh Wilopo (2006) melakukan penelitian mengenai analisis faktor-faktor yang berpengaruh terhadap kecenderungan kecurangan akuntansi pada BUMN dan perusahaan terbuka yang diukur dengan variabel bebas: sistem pengendalian intern, kesesuaian kompensasi, ketaatan akuntansi, asimetri informasi dan moralitas manajemen, terhadap perilaku tidak etis dan kecenderungan kecurangan akuntansi sebagai variabel independen. Mengacu dari penelitian terdahulu bahwa penelitian ini memiliki beberapa persamaan dan perbedaan diantaranya penelitian secara umum telah dilakukan terkait pengendalian internal dan sistem kompensasi terhadap kecurangan. Dalam penelitian ini yang menjadi perbedaan adalah penelitian sistem kompensasi yang tepat terhadap karyawan dalam mengurangi tindakan fraudelent financial reporting dilakukan secara mendalam dan spesifik pada kecurangan pelaporan keuangan. Selain itu penelitian ini menggunakan tambahan variabel moderating motivasi kerja. Peneliti juga menggunakan penelitian yang dilakukan oleh Bryan K. Church, Theresa Libby, dan Ping Zhang (2008) yang berjudul "Contracting Frame and Individual Behavior: Experimental Evidence" sebagai referensi. Perbedaan dan persamaan dengan penelitian yang dilakukan oleh peneliti yaitu peneliti tidak menggunakan penilaian dari masing-masing individu tentang perkerjaan yang dilakukan melainkan peneliti lebih melakukan pengukuran dari tingkat motivasi dari setiap individu. Selain itu yang menjadi persamaan dalam penelitian ini adalah tentang pengaruh skema kompensasi terhadap tindakan kecurangan secara umum. Peneliti juga menggunakan penelitian yang dilakukan oleh Herpen dan Praag (2004) meneliti tentang hubungan sistem pengukuran kinerja dan system pemberian 


\section{JURNAL NOMINAL / VOLUME V NOMOR 1 / TAHUN 2016}

kompensasi terhadap kinerja dengan motivasi sebagai variabel pemoderasi. Hasil yang diperoleh dari penelitian ini adalah bahwa kompensasi dan kondisi kerja baik secara parsial maupun bersama-sama mempengaruhi kinerja karyawan dan motivasi memperkuat pengaruh kompensasi dan kondisi kerja terhadap kinerja karyawan. Perbedaan dan persamaan dengan penelitian yang dilakukan oleh peneliti yaitu peneliti juga menggunakan variabel motivasi kerja yang digunakan sebagai variabel moderasi dan variabel independen yaitu system kompensasi meskipun dalam penelitian yang dilakukan Herpen dan Praag tidak secara khusus memilih sistem kompensasinya, sedangkan yang menjadi perbedaaan peneliti tidak menggunakan variabel kinerja sebagai variabel dependen melainkan menggunakan variabel fraudelent financial reporting dan menggunakan variabel reward dan punishment sebagai variabel independen.

\section{METODE PENELITIAN}

\section{Jenis Penelitian}

Penelitian ini menggunakan pendekatan kuantitatif dengan jenis penelitian eksperimen.

\section{Waktu dan Tempat Penelitian}

Penelitian ini dilakukan di Universitas Negeri Yogyakarta Penelitian eksperimen ini melibatkan karyawan bagian keuangan UNY. Penelitian ini dilaksanakan pada bulan Desember 2015 sampai dengan Februari 2016.

\section{Target/Subjek Penelitian}

Subyek penelitian ini adalah pegawai bagian keuangan Universitas Negeri Yogyakarta. Penelitian ini menggunakan data populasi yang berjumlah 82 pegawai. Data responden yang dapat digunakan dan diolah dalam penelitian ini adalah 75 data responden.

\section{Prosedur}

Penelitian eksperimen ini dilaksanakan pada pegawai bagian keuangan Universitas Negeri Yogyakarta. Instrumen penelitian dibagi secara acak (random). Subjek penelitian hanya mendapat sebuah kondisi instrumen kasus.

Sebelum subjek penelitian mengerjakan instrumen kasus, peneliti memberikan penjelasan mengenai kasus yang ada. Peneliti juga menjelaskan alur pengisian instrumen mulai dari data demografi, kolom keputusan tindakan yang diambil, sampai dengan manipulation check.

\section{Data, Intrumen, dan Teknik Pengum- pulan}

\section{Data}

Data yang digunakan dalam penelitian ini adalah data primer yang diperoleh langsung dari obyek penelitian. Semua responden dengan jenis kompensasi yang ditentukan secara acak harus mengikuti beberapa tahap ekperimen. 


\section{Teknik Analisis Data}

Teknik pengujian kualitas data dan menganalisis data dalam penelitian ini dilakukan melalui tahap yakni yang pertama pengujian instrumen dalam pengujian instrumen peneliti melakukan pengujian secara langsung pada populasi yang terpakai, jika ada butir pertanyaan yang tidak valid maka peneliti langsung melakukan eliminasi pada nomor butir pertanyaan tersebut. pengujian instrument penelitian ini menggunakan uji validitas dan uji reliabilitas. Peneliti dalam menguji hipotesis menggunakan analiss of variance (anova) untuk menguji hipotesis yang diusulkan. Anova digunakan untuk membandingkan rata-rata dari populasi.

\section{HASIL PENELITIAN DAN} PEMBAHASAN

Pengujian hipotesis dalam penelitian ini menggunakan Analysis of Variance (ANOVA). ANOVA digunakan untuk menguji hubungan antara variabel dependen (skala metrik) dengan satu atau lebih variabel independen (skala nonmetric atau kategorikal).Pengujian hipotesis ini dilakukan pada batas signifikansi sebesar $5 \%$.
Tabel 1. Hasil Uji Hipotesis dengan ANOVA

Variabel Dependen: Fraudelent

Financial Reporting

\begin{tabular}{lcrl}
\hline \multicolumn{1}{c}{ Variabel } & F & Sig & \multicolumn{1}{c}{ Ket } \\
\hline Skema & 93,812 & 0,00 & H1 \\
Reward & & & Diterima \\
\hline Skema & 292,33 & 0,00 & H2
\end{tabular}

Punishment 2 Diterima

$\begin{array}{llll}\text { Skema } & 319,86 & 0,00 & \text { H3 }\end{array}$

Reward \& 11 Diterima

Punishment

\begin{tabular}{llll}
\hline Skema & 275,79 & 0,00 & H4
\end{tabular}

Reward 9 Diterima

*Motivasi

Kerja

$\begin{array}{llll}\text { Skema } & 154.02 & 0,00 & \text { H5 }\end{array}$

Punishment 1 Diterima

*Motivasi

Kerja

$\begin{array}{llll}\text { Skema } & 196.53 & 0,00 & \text { H6 }\end{array}$

Reward \& 5 Diterima

Punishment

*Motivasi

Kerja

Dari hasil di atas dapat dibuat kesimpulan bahwa semua hipotesis dapat diterima.

Pengaruh Skema Kompensasi Reward terhadap Fraudelent Financial Reporting. Hasil Uji ANOVA yang ditunjukkan pada 


\section{JURNAL NOMINAL / VOLUME V NOMOR 1 / TAHUN 2016}

tabel di atas dapat diketahui bahwa terdapat pengaruh antara Skema Kompensasi Reward terhadap Fraudelent Financial Reporting. Hal ini dapat dilihat pada hasil perhitungan dari nilai $\mathrm{F}$ sebesar 93,812 dan signifikansi sebesar 0,00. Nilai $\mathrm{P}_{\text {value }}$ signifikansi kurang dari 0,05. Hasil ini menunjukkan bahwa Skema Kompensasi Reward memberikan pengaruh positif pada Fraudelent Financial Reporting. Dapat disimpulkan bahwa hasil pengujian ini mendukung H1 yaitu Skema Kompensasi Reward akan berpengaruh terhadap Fraudelent Financial Reporting.

Pengaruh Skema Kompensasi Punishment terhadap Fraudelent Financial Reporting. Hipotesis kedua yang diajukan oleh peneliti adalah Punishment berpengaruh terhadap Fraudelent Financial Reporting. Hasil Uji ANOVA yang ditunjukkan pada tabel di atas dapat diketahui bahwa terdapat pengaruh antara Skema Kompensasi Punishment terhadap Fraudelent Financial Reporting. Hal ini dapat dilihat pada hasil perhitungan dari nilai F sebesar 292,232 dan signifikansi sebesar 0,00 . Nilai $\mathrm{P}_{\text {value }}$ signifikansi kurang dari 0,05. Hasil itu menunjukkan bahwa Skema Kompensasi Punishment memberikan pengaruh pada Fraudelent Financial Reporting atau $\mathrm{H} 2$ diterima. Dapat disimpulkan bahwa hasil pengujian ini mendukung Skema Kompensasi Punishment berpengaruh terhadap Fraudelent Financial Reporting.
Pengaruh Skema Kompensasi Reward dan Punishment terhadap Fraudelent Financial Reporting. Hasil Uji ANOVA yang ditunjukkan pada tabel di atas dapat diketahui bahwa terdapat pengaruh antara Skema Kompensasi Reward dan Punishment terhadap Fraudelent Financial Reporting. Hal ini dapat dilihat pada hasil perhitungan dari nilai $\mathrm{F}$ sebesar 319,861 dan signifikansi sebesar 0,00. Nilai $\mathrm{P}_{\text {value }}$ signifikansi kurang dari 0,05. Hasil ini menunjukkan bahwa Skema Kompensasi Reward dan Punishment memberikan pengaruh pada Fraudelent Financial Reporting. Dapat disimpulkan hasil penelitian ini menerima $\mathrm{H} 3$ yaitu Skema Kompensasi Reward dan Punishment akan berpengaruh terhadap Fraudelent Financial Reporting.

Motivasi Kerja Memoderasi Pengaruh Skema Kompensasi Reward terhadap Fraudelent Financial Reporting. Hipotesis keempat yang diajukan oleh peneliti adalah Motivasi Kerja memoderasi hubungan Skema Kompensasi Reward terhadap Fraudelent Financial Reporting. Hasil Uji ANOVA yang ditunjukkan pada tabel di atas dapat diketahui bahwa nilai $\mathrm{F}$ adalah 275,799 sedangkan $\mathrm{P}_{\text {value }}$ signifikansi sebesar 0,00. Kriteria untuk hipotesis yang diterima adalah $\mathrm{P}_{\text {value }}$ kurang dari 0,05 dengan demikian hipotesis keempat diterima. Motivasi Kerja memoderasi Skema Kompensasi Reward terhadap Fraudelent Financial Reporting. Dari hasil 


\section{JURNAL NOMINAL / VOLUME V NOMOR 1 / TAHUN 2016}

di atas maka Motivasi Kerja memperkuat pengaruh Skema Kompensasi Reward terhadap tindakan Fraudelent Financial Reporting.

Motivasi Kerja Memoderasi Pengaruh Punishment terhadap Fraudelent Financial Reporting. Hasil Uji ANOVA yang ditunjukkan pada tabel di atas dapat diketahui bahwa variabel motivasi kerja memberikan pengaruh terhadap Skema Kompensasi Punishment terhadap Fraudelent Financial Reporting. Tabel di atas menunjukkan bahwa nilai $\mathrm{F}$ adalah 154,021 sedangkan $\mathrm{P}_{\text {value }}$ signifikansi sebesar 0,00. Kriteria untuk hipotesis yang diterima adalah $\mathrm{P}_{\text {value }}$ kurang dari 0,05 sehingga dapat disimpulkan bahwa hipotesis kelima diterima. Motivasi Kerja memoderasi pengaruh Skema Kompensasi Punishment terhadap Fraudelent Financial Reporting.

Motivasi Kerja Memoderasi Pengaruh Skema Kompensasi Reward dan Punishment terhadap Fraudelent Financial Reporting. Hipotesis keenam yang diajukan oleh peneliti adalah Motivasi Kerja memoderasi hubungan Skema Kompensasi Reward dan Punishment terhadap Fraudelent Financial Reporting. Dapat diketahui bahwa nilai perhitungan dari nilai $\mathrm{F}$ sebesar 196,535 dan signifikansi sebesar 0,00 . Nilai $\mathrm{P}_{\text {value }}$ signifikansi kurang dari 0,05. Hasil ini menunjukkan bahwa Motivasi Kerja memoderasi pengaruh Skema Kompensasi
Reward dan Punishment terhadap Fraudelent Financial Reporting. Dapat disimpulkan hasil pengujian ini menerima H6.

Tabel 2. Mean Fraudelent Reporting

\begin{tabular}{ll}
\hline Skema Kompensasi & Mean \\
\hline Skema Reward & 5,44 \\
\hline Skema Punishment & 5,35 \\
\hline Skema Reward dan & 5,42 \\
Punishment & \\
\hline Skema Netral & 2,33
\end{tabular}

Berdasarkan tabel di atas maka dapat dibuat grafik yang menunjukkan kinerja skema kompensasi sebagai berikut ini:

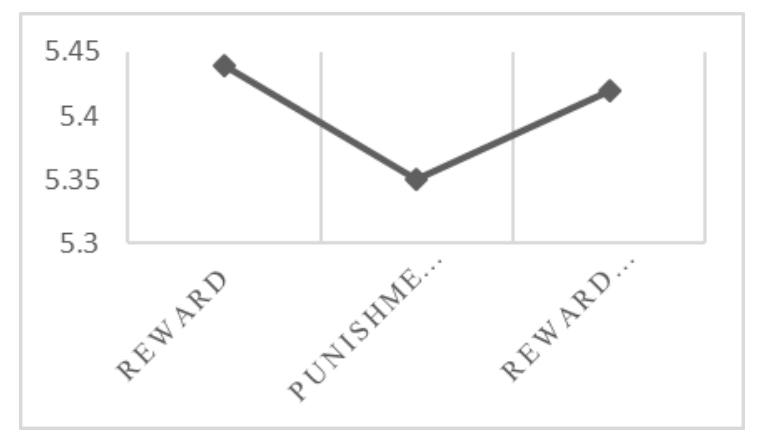

Gambar 1. Mean Fraudelent Financial Reporting

\section{SIMPULAN DAN SARAN}

\section{Simpulan}

Penelitian ini bertujuan untuk menguji pengaruh skema kompensasi reward, punishment terhadap fraudelent financial reporting dengan motivasi kerja sebagai variabel moderating (studi eksperimen pada Pegawai Keuangan Universitas Negeri 
Yogyakarta) dari hasil pengujian yang telah dilakukan peneliti dapat disimpulkan bahwa ke enam hipotesis yang ada diterima dan berpengaruh positif.

\section{Saran}

Bagi instansi pemberian kompensasi berupa Reward dan Punishment perlu diterapkan guna memberikan semangat dan motivasi bagi karyawan supaya berkerja sesuai harapan instansi. Motivasi kerja karyawan perlu dijaga dengan baik oleh atasan supaya karyawan berkerja dengan baik dan menghindari tindakan tidak jujur dalam bekerja.

Bagi penelitian selanjutnya sebaiknya memberikan pilihan skema kompensasi yang lebih banyak bukan sekedar Reward dan Punishment saja supaya pilihan kompensasi dari responden terwakili sesuai dengan harapanya.

Penelitian sebaiknya diperluas dalam hal pemilihan instansi yang memiliki populasi baik dalam segi kuantitas maupun kualitas disesuaikan dengan proksi penelitian.

\section{DAFTAR PUSTAKA}

ACFE. (2012). Report To The Nation On Occupational Fraud And Abuse

Alisa G Brink dan Frederick. (2013). The Effects of Risk Preference and Loss Aversion on Individual Behavior under Bonus, Penalty, and Combined
Contract Frames. Behavior Research in Accounting 25: Hlm. 145-170

Anwar Prabu Mangkunera. (2013). Manajemen Sumber Daya Manusia Perusahaan. Bandung: Remaja Rosdakarya

Baucus, Melissa S \& Caryn L Beck-Dudley. 2005. Designing Ethical Organizations: Avoiding the LongTerm Negative Effects of Rewards and Punishments. Journal of Business Ethics 56: 355-370, 2005.

Caesar Marga Putri. (2012). Pengujian Keefektifan Model Whistleblowing: Pendekatan Eksperimen. Yogyakarta: Tesis Universitas Gajah Mada

Chruch, B. K., T. Libby, dan P. Zhang. (2008). Contracting Frame and Individual Behavior: Experimental Evidence. Journal of Management Accounting Research 20: Hlm. 153168.

Dymita A Kristanti. (2012). Persepsi Mahasiswa Terhadap Peran Akuntansi Forensik Sebagai Pencegah Fraud di Indonesia: Skripsi Fakultas Ekonomi Universitas Negeri Yogyakarta

Eni Nurmiyati. (2011). Hubungan Pemberian Reward dan Punishment dengan Kinerja Karyawan pada BPRS Harta Insan Karimah. Jakarta: Skripsi Fakultas Syariah dan Hukum UIN Syarif Hidayatullah

Eriksson, Tor \& Jaime Ortega. 2004. The Adoption of Job Rotation:Testing the Theories. Aarhus, Denmark: Department of Economics, Aarhus School of Business Diunduh pada 23 September 2015 dari http://www.hha.dk/nat/wper/04$\underline{3 \text { tor.pdf }}$

Galih Dwi Koencoro, dkk. (2013). Pengaruh Reward dan Punishment terhadap 


\section{JURNAL NOMINAL / VOLUME V NOMOR 1 / TAHUN 2016}

kinerja: Survey pada karyawan PT Inka Madiun. Student Journal Universitas Brawijaya. Vol 5, No 2, 2013

Gendro Wiyono. (2011). Merancang Penelitian Bisnis dengan Alat Analisis SPSS dan Smart PLS. Yogyakarta: UPP STIM YKPN

Gugup Kismono. (2010). Bisnis Pengantar. Yogyakarta : BPFE

Hannan, R. L., V. B. Hoffman dan D. V. Mosser. (2004). Bonus versus Penalty: Does Contract Frame Affect Employee Effort?. Experimental Business Research 2: Hlm. 151-169

Hasibuan, Malayu S.P. (2010). Manajemen Sumber Daya Manusia Edisi revisi. Jakarta: Bumi Aksara

Herpen, Marco Van dan Marco Van Praag. (2004). Wage Structure and The Incentive Effect of Promotions. Tinbergen Institute Discussion Paper Vol.3 No.20; April 2004

Imam Ghozali. (2009). Aplikasi Analisis Multivariate dengan Program SPSS. Semarang: Badan Penerbit Universitas Diponegoro

Ivancevich, Konopaske Dan Matteson. (2007). Perilaku Manajemen Dan Organisasi: alih bahasa Gina Gania. Jakarta : Erlangga.

Joseph, Fadipe \& Titiloye. (2012). Application of Continued Fractions in Controlling Bank fraud. International Journal of Business and Social Science Vol. 3 No. 9; May 2012

KNKG. (2008). Pedoman sistem pelaporan pelanggaran-SPP (whistleblowing system-WBS)

Moeheriono. (2006). Pengukuran Kinerja Berbasis Kompetensi. Jakarta: Raja Grafindo Persada.
Murphy, Pamela R \& M Tina Dacin. (2011). Psychological Pathways to Fraud: Understanding and Preventing Fraud. Journal of Business Ethics (2011) 101:601-618

Nur Indriantoro dan Bambang Supomo. (1999). Metodologi Penelitian Bisnis Untuk Akuntansi \& Manajemen. Yogyakarta: BPFE

Nurati Jatiningtyas. (2011). Analisis FaktorFaktor yang Mempengaruhi Fraud Pengadaan Barang/Jasa pada Lingkungan Instansi Pemerintah di Wilayah Semarang. Semarang : Skripsi Fakultas Ekonomi Universitas Diponegoro

Raja Ali, dkk. (2011). Analisis Reward dan Punishment pada Kantor Perum Damri Makasar. Makasar : UNHAS

Robert dan Vijay Goivindarajan. (2005). Management Control System. (Alih bahasa: Drs F.X. Kurniawan Tjakrawala, Msi, Akt dan Krista S.E, Ak) Jakarta: Salemba Empat

Rosmita Dewi Yuniarti \& Nelly Nur Apandi. (2013). Gejala Fraud Dan Peran Auditor Internal Dalam Pendeteksian Fraud Di Lingkungan Perguruan Tinggi (Studi Kualitatif). Bandung: Skripsi Universitas Pendidikan Indonesia

Sekaran, Uma. (2006). Research Methods For Business Jilid 2. Edisi 4. Jakarta: Salemba Empat.

Shanikat, Mohammad et. al. 2014. Occupational Fraud Prevention Mechanisms: Jordan Companies Experience. Research Journal of Finance and Accounting. Volume 5, No. 1,2014

Sugiyono. (2012). Statistika untuk Penelitian. Bandung: Alfabeta Bandung

Sung and Choi. (2009). Do Big Five Personality Factors Affect Individual 
Creativity? The Moderating Role of Extrinsic Motivation. Journal of Social Behavior and Personality 20: Hlm. 143156

Toto Sugiharto. (2009). "Analisis Varians". Modul. Universitas Gunadarma

Veithzal Rivai \& Ella Jauvani Sagala. (2009). Manajemen Sumber Daya Manusia Untuk Perusahaan: Dari Teori ke praktik. Jakarta: PT. Raja Grafindo Persada

Wells, Joseph T. (2001). Journal of Accountancy: "Why Employees Commit Fraud". American Institute of Public Accountants

Wilopo. (2006). Analisis Faktor-Faktor Yang Berpengaruh Terhadap Kecenderungan Kecurangan Akuntansi: Studi Pada Perusahaan Publik Dan Badan Usaha Milik Negara di Indonesia. Jurnal Riset Akuntansi Indonesia. Vol. 9 No.3 : 346366

Xu, Yin, \& Douglas E. Ziegenfuss, D. (2008). Reward Systems, Moral Reasoning, and Internal Auditors' Whistle-Blowing Wrongdoing Behavior. Journal of Business Psychology, Vol 22. Pp 323331.

Zimbleman, Mark et.al (2009). Fraud Examination. third edition. South Western Cengage Learning : USA 